\title{
War and Pensions: The Effects of War on Social Security and Pensions Around the World
}

\author{
John A. Turner ${ }^{1}$, David M. Rajnes ${ }^{1}$, Gerard Hughes ${ }^{2} \&$ Michelle Maher ${ }^{3}$ \\ ${ }^{1}$ Pension Policy Center, Washington, DC USA \\ ${ }^{2}$ Trinity College, Dublin, Ireland \\ ${ }^{3}$ Maynooth University, Maynooth, Ireland \\ Correspondence: John A. Turner, Pension Policy Center, 3713 Chesapeake St. NW, Washington, DC 20016 USA. \\ E-mail: Jaturner49@aol.com
}

Received: December 9, 2019

Accepted: January 26, 2020

Online Published: January 29, 2020

doi:10.5539/ijef.v12n2p45

URL: https://doi.org/10.5539/ijef.v12n2p45

\begin{abstract}
War has affected the development of social security and employer-provided pensions. Roman soldiers received the first pensions. In most countries, military pensions preceded social security pensions, providing countries experience with the concept and administration of pensions. War or the threat of war affected the development of the two major branches of social insurance-based pensions-Bismarckian (earnings related pensions developed in Germany) and Beveridgian (pensions tied to years of work developed in the United Kingdom). War has affected the choice countries make between funded and unfunded or pay-as-you-go pensions. The money in funded social security pensions can be expropriated to finance wars. Periods of hyperinflation following wars have destroyed funded social security pensions and funded employer-provided pensions in some countries. A victor country can have a major effect on the pensions in a defeated country. Social security pensions can be used to encourage national solidarity during and after wars. In the twenty-first century, social security pensions have been the target of cyber warfare.
\end{abstract}

Keywords: social security pensions, war, pension funding

\section{Introduction}

Pensions and war have a long historical connection. "Pension" was the term used for post-service payments to Roman soldiers. Initially, Rome paid veterans land grants, fearing that dissatisfied veterans might start rebellions. Later, Rome substituted cash payments, which were the first modern-form pensions (Craig, 2003). In many countries, military disability pensions were the first pensions, followed by military retirement pensions, then civil service pensions for government employees, then other employer-provided pensions, then social security pensions.

Funded pensions are a potential source of funds for other purposes, such as wars. Because they can play an important role in labor and capital markets, they can consequently be a target in modern warfare. Because the value of funded pensions can be destroyed in modern warfare, war can affect the choice between funded and unfunded pensions. We, however, do not argue that war always has an effect on social security programs. Rather, the historical record indicates that often, but not always, war has played a role in the start, and less commonly in the later historical development, of social security programs. We discuss situations where war is more likely to affect social security.

While war is clearly not the only factor affecting the development of social security and employer-provided pensions, we focus on the effects of war on the historical development of those pensions. This focus is taken because other studies have often overlooked the effects of war, and no previous study has undertaken a broad survey of the effects of war on social security and employer-provided pensions. War is taken to include a range of types of group conflict, including 'cold' war, civil war, insurrections, guerrilla warfare, cyber warfare, and terrorism.

The paper is structured as follows. First, we review the limited previous literature on the effects of war on pensions. We present a simple demand-supply model for organizing the analysis of effects of war on pensions. We then consider the effects of war on the development of social security pension systems. This discussion is divided into three sections. First, we consider military precursors to social security pensions. Second, we discuss effects of war 
on the start of social security pensions. Third, we discuss effects of war on existing social security pensions. Then we discuss effects of war on employer-provided pensions. We end the paper with a summary and conclusions.

\section{Literature Review}

National mandatory pensions systems provided by government are referred to in the literature and around the world by different terms, including social security pensions, public pensions and state pensions. In this paper we use the terminology of social security pensions. While a number of authors have examined the development of the European welfare states and more generally the development of social welfare policy, and some have touched on the topic of war and pensions, relatively few academic authors have focused on the effects of war on pensions. Previous studies of the development of pension systems have often overlooked the role of war and conflict. For example, Collier and Messick (1975) discuss factors affecting the adoption of social security pensions but do not consider the effects of war.

In this section, we discuss the few academic papers that have focused on the effects of war on pensions. In the remainder of the paper, we also reference a number of papers that have touched on that topic.

Perotti and Schwienbacher (2009) empirically analyze the differences across countries in the use of funding in social security and employer-provided pension systems. They conclude that countries that have experienced hyperinflations, primarily following World War I and World War II, are more likely to have lower pension funding relative to GDP. Hyperinflations generally occur when wars make it difficult for governments to collect taxes. Governments then print money to pay for their expenses, which leads to inflation. They argue that the effects of hyperinflation on the choice between state provision and private provision of retirement income, favoring social security pay-as-you-go systems, were subsequently rationalized by ideology concerning the role of the state in society.

Kasza (2006) analyses the effects of World War II on the development of social security pensions in Japan. He finds that the war had major, long-term effects. He hypothesizes that mass participation in war fosters an egalitarian sense of social justice that encourages the development of social security pensions. The Japanese wartime slogan "all people are soldiers" was later changed to "all people should have pensions."

Minns (2007) argues that most analyses of social security pension reforms involving individual account pensions in Latin America do not take into account the role of international debt and the reasons for it. Individual account pensions are defined contribution pensions where the amount of contributions is determined, while the benefits they provide are not predetermined by a benefit formula, but depend on the account balance at retirement. Argentina incurred substantial debt to buy weapons during the 1976-83 military junta. The weapons purchases were to fight communist groups in the country. In 1984, social security pensions were cut to pay for the growing national debt. In 2001, Argentina defaulted on its debt. This adversely affected the individual account pensions because they were largely invested in government debt.

\section{Demand, Supply and the Evolution of Pension Systems}

To structure the analysis of the different effects of war on pensions, we outline a simple model of the demand for pensions by workers and the supply of pensions by government. Workers have a demand for pensions to provide economic security in retirement. The demand for pensions by workers in voluntary pension systems is affected by the incentives to save through pensions relative to other forms of savings. These incentives primarily take the form of preferential tax treatment of pensions. The demand of workers for social security pensions is affected by the availability of alternative sources of income in old age, including employer-provided pensions, family support, and opportunities for work. The demand for pensions is also affected by the views of workers as to the appropriate role for government compared to employer or individual provision of retirement income.

The supply of pensions by government is affected by factors affecting the cost of providing pensions. It is also affected by the ideology of the ruling power in countries where social security systems are imposed by foreign governments, such as during the imposition of communism in a number of countries following World War II. The ability to collect contributions in contributory pension systems is a factor affecting the supply of pensions. The historical experience that governments have in providing pensions to the military increases its ability to provide pensions on a wide scale.

For unfunded pensions, the ratio of beneficiaries to covered workers is an important aspect of the cost, acting as a shadow price to workers for providing benefits (Turner, 1984). For example, when there are five workers for every beneficiary, it costs each worker 0.2 euros to provide a benefit of one euro. Because of the role of the old-age dependency ratio in funding pay-as-you-go pensions, one of the ways that war affects the cost of providing pensions is by affecting the population age structure. 
The demand and supply framework is a static framework. Pension systems evolve over time, with changes at a particular point in time depending in part on the changes that have occurred up to that time. Thus, we organize the paper in a dynamic or evolutionary framework. We distinguish demand and supply effects in three time periods1) precursors to social security pensions, 2) the start of social security, and 3) pensions already established.

\section{Military Pensions as Precursors to Social Security Pensions}

The paper now turns to a survey of how military pensions led to the development of social security pensions and employer-provided pensions. The needs of older veterans created a demand for pensions.

England and Ireland. In Ireland, the Royal Hospital Kilmainham, built in 1680, and in England, the Royal Hospital Chelsea, founded in 1682, were retirement homes for veterans. The government providing retirement homes rather than a pension was inspired by Les Invalides, the retirement home for French veterans in Paris. During the reign of King William III, the Royal Hospital Chelsea was still being built, so in 1689 England established a system for distributing army pensions. The pension was for former soldiers injured in service, or who had served for more than 20 years. By the time the Chelsea Hospital was completed, the number of pensioners exceeded the hospital's capacity. Only veterans not living in the hospital received a pension. The hospital was responsible for distributing army pensions until 1916 (Jones, Palmer, \& Wessely, 2002; Wikipedia, 2017).

Sweden. Military pensions developed in Sweden in the $17^{\text {th }}$ century. Initially, housing was provided for disabled veterans, but as their number grew due to frequent wars, payments were made instead in the form of grain, then later in cash. The first pension fund was established by the Swedish Navy in 1642, with sailors having pay withheld from their wages and deposited into the fund (Hagen, 2013).

United States. The Civil War Pension Plan in the United States started in 1862, and initially was only for disabled soldiers (Skocpol, 1992). Later veterans disabled for any clause became eligible. By 1890, the disability requirement was dropped and eligibility for veterans was based solely on age (Gross, 2005). Thus, over time, the Civil War Pension Plan evolved to have features that eventually were part of U.S. Social Security system.

The effects of war, and a resulting military pension system, on encouraging the development of social security pensions can occur decades later. The Social Security Act was passed 70 years after the end of the Civil War, but the Civil War Pension Plan continued providing benefits for decades later, even into the $21^{\text {st }}$ century for children of Civil War veterans (Frizell, 2014). The U.S. Social Security Administration views the Civil War Pension Plan as a precursor to Social Security in the United States in part because it was the first large scale pension plan in the U.S. (Social Security Administration, 2014). By raising public awareness of the benefits of a pension system, it increased public support for a social security program. Another factor in the development of social security in the U.S. was that the government gained experience in pension administration through its experience with the Civil War Pension Plan.

Japan. In 1883, Japan established a pension system for the military and high government officials (Watanabe, 1996). This system was a precursor to the development of other pensions in Japan. In 1939, at the start of World War II, Japan established the Seaman's pension fund because Japanese shipping was being attacked and seamen were being wounded and killed. Shortly after that, Japan established a social security program for nearly all Japanese.

Canada. Following World War I, Canada provided survivor and disability pensions for war veterans and their families with the Pension Act (1918). Public support for a social security program increased after the war, as social advocates and some politicians argued that the federal government should extend the pension provisions offered to war veterans. In 1927, Canada passed the first social security Old Age Pension Act (Canadian Museum of History, 2015).

\section{The Start of Social Security Pensions}

With social insurance-based pensions, risks are shared across workers and their families, while with individual account pensions financial market risks are borne entirely by the individual worker due to fluctuations in the value of his or her individual account. War can affect the choice between social insurance and individual account pensions. War tends to strengthen feelings of national solidarity and shared purpose, which creates a demand for social insurance-based pensions.

The two main types of traditional social insurance-based social security pension programs are called Bismarckian or Beveridgian, in recognition of the people instrumental in their founding-Otto von Bismarck, Chancellor of Germany and William Henry Beveridge, an economist in the United Kingdom. While war is not the only factor affecting the development of these two forms of social security pensions, it affected the early development of both. 
Von Bismarck began social security pensions in Germany as a way to reduce the risk of class warfare. His goal was to help people maintain their standard of living in retirement. Social security pension systems providing pensions that are based on earnings and contribution periods are called Bismarckian.

By contrast, the United Kingdom built on the existing poor relief laws and provided pensions that reduced poverty among retirees. Social security pension systems based on years of earnings or contributions are called Beveridgean.

Germany. Chancellor Otto von Bismarck developed the world's first social security pension through the Old Age and Disability Insurance Law of 1889 (Gildea, 2003). Bismarck combined anti-socialist laws passed in 1879 with a mandatory system of social security pensions. This program provided the foundation for social security pensions in Canada, Japan, the United States and many other countries. His desire to gain working class support that might otherwise have gone to Socialists, and that might have resulted in class warfare, motivated him to use social security as a deliberate means 'to weaken popular support for socialist parties by ameliorating the social conditions of industrial workers, and by directly linking their welfare to the security and economic strength of the central state' (Arza \& Johnson, 2006).

United Kingdom. The Beveridge Report, formally known as the report on Social Insurance and Allied Services, is the foundation of British social security programs. It was introduced in Parliament in 1942. John Maynard Keynes provided advice on the financing of Beveridge's proposal. He favored pay-as-you-go financing as prefunding would be “... a severe burden to meet simultaneously pensions against which no funds have been accumulated and to accumulate funds for future pensions" (Keynes, 1980).

William Beveridge argued that the sense of national unity and readiness to sacrifice personal interests to the common cause during a time of war made it possible to bring about societal changes that would be acceptable to all but that would have been difficult to make at other times (Ring, 1943). The report promised a reward for the wartime sacrifices of the nation, which was a more just society better providing for its older citizens. To the extent that war encourages feelings of national solidarity, it encourages the demand for the development of traditional social security pensions rather than individual account pensions. Bauer et al. (2016) present evidence that war encourages social cohesion within a country. That effect could be instrumental in the development of social insurance type social security programs in some countries.

World War II was a critical juncture for pension systems. Critical junctures are brief opportunities for major institutional reform. They are critical because they make institutional arrangements which become difficult to later change (Pierson, 2004). By 1945, the world had come through the Great Depression, World War II, and turbulent, repressive politics in some countries. The term 'post-war consensus' describes how governments in different countries pursued similar policies, such as full employment and the welfare state (Heffernan, 2002). The theory of post-war consensus argues that leaders of western industrialized nations, informed by Keynesianism, pursued development of the modern welfare state, including social security pension systems (Graham \& Seldon, 1990; Kavanagh \& Morris, 1994; Judt, 2005).

International Labour Organization. The International Labour Organization (ILO) has been an influential international actor in the development and reform of social security pensions, with World War I and World War II both playing a role in its development. The ILO was established in 1919, following World War I, as part of the League of Nations, and became an important proponent of social insurance ideology (Arza \& Johnson, 2006; Deacon, 2007). It was influential in creating a demand for social security pension adoption and expansion in countries around the world, whether using a Bismarckian or Beveridgean approach. It played a key role in arguing for social security systems to be part of the peace following World War I.

In 1944, anticipating the end of World War II, the International Labour Conference in Philadelphia provided further impetus for expanding social security pension systems. The Philadelphia Declaration recognizes that "economic security should be a right for all people and that the nations of the world should develop programmes which will achieve ... the extension of social security measures to provide a basic income to all in need of such protection" (International Labour Organization, 1944). The Philadelphia Declaration was endorsed by the major victorious powers as the approach for a new peaceful post-war social order, and while pensions were only one part of its vision, the ILO created momentum behind pension system development in countries around the world (Orenstein, 2008).

\section{The Choice between Funded and Unfunded Pension Systems}

One of the fundamental decisions in designing a social security pension system is whether it should be funded or unfunded (pay-as-you-go). With funded pension systems, money is set aside in advance to assure that there will be sufficient money to pay for future benefits. With unfunded pension systems, current workers pay for the benefits 
of current retirees. These two types of pension systems are subject to different risks, including those risks that war poses. The two types of systems are also supported by different ideologies. Social insurance pensions, which are unfunded or partially funded systems, are based on an ideology of shared risks by workers. Individual account pensions, which generally are funded pensions, are based on an ideology of individualism, with individual's bearing the full risks relating to the investment of their accounts.

After World War II, the trend was towards social security pensions financed on a pay-as-you-go (PAYG) basis. Two world wars caused a drastic reduction in public assets that reduced the ability of governments to provide funded social benefits (Natali, 2008). The move to PAYG allowed politicians to maintain a social security pensions policy that respected the welfare rights of the generations that had fought in wars and subsequently had a limited working lifetime in the post-war boom economy to accrue pensions.

Destruction of the monetary value of funded social security pensions due to war-related inflation. Hyperinflation can also affect the choice between funded and unfunded pensions. Hyperinflation can be caused by war and the aftermath of war, when governments have difficulty raising money through taxation and resort instead to financing government expenditures through printing money. Hyperinflation destroys the monetary value of funded pensions, and thus affects the ability of governments to provide funded pensions. A result is that worker trust in the ability of government to provide funded pensions is greatly reduced.

France. Before World War II, France began a fully funded social security pension system two times - in 1910 and 1930. Each time the monetary value of the funding was wiped out due to subsequent high wartime inflation - and in the end, the government converted them into means-tested support for the poor elderly. War-time inflation during World War II decimated the value of the social security funds, and by the end of the World War II the program was effectively financed on a pay-as-you-go basis. The effects of World War I and II on social security pension plans in France "totally discredited" funding (Lynes, 1985). Consequently, France in 1945 ended the funded approach and developed a pay-as-you-go system (Capretta, 2007).

Austria. Austria experienced hyperinflation following World War I. Arguably as a consequence, the unfunded social security program dominates the provision of retirement income, with funded pensions playing a small role.

Italy. The evolution of Italy's social security pension program is similar to that in many continental European countries. Established in 1919 on a funded basis, after World War II, with its reserves decimated by high wartime inflation, Italy established a pay-as you-go system (Capretta, 2007).

\section{Effects of War on Established Social Security Pensions}

Use of pensions to finance wars. Funded pension systems can accumulate a substantial amount of money, which can make them a target to be "raided" by governments to finance wars. The use of social security funds to finance war affects the ability of government to provide or supply funded pensions.

Japan. Because benefits in new pension systems are sometimes not paid for many years, the initial build-up of assets can be used to finance war. In 1942, during World War II, Japan introduced the first social security pension for private sector workers. The contribution rate was set at 11 percent. One of the reasons why Japan started the system during World War II was that the government wanted to reduce consumer spending in order to control inflation and to help finance the war. Between 1942 and 1945, because few people qualified to receive benefits, nearly all of the social security contributions went to pay for the war. Because of the widespread poverty after the war, the contribution rate was reduced to 3 percent (Kasza, 2006, National Institute of Population and Social Security Research, 2014).

Russia. In 2002, Russia established a social security pension system where employers contribute 6 percent of salary to mandatory individual account private pension funds, while they contribute 16 percent to the social security fund. (Employees do not contribute.) In 2013, Russia made the 6 percent voluntary, with the default being that all 22 percent would go to the state. Because of the expense of the annexation of Crimea and war in other parts of the Ukraine in 2014-16, and because of the effect of the resulting economic sanctions against Russia, the Russian government experienced serious budget shortfalls. To help pay for its budget, government leaders approved for 2014 and 2015 diverting funds workers contributed to privately managed pension accounts into the government's social security pension fund, giving workers social security credits. In 2014, this policy resulted in about $\$ 7$ billion being transferred from individual account pension funds to the social security fund. This transfer reduced the amount of money the state needed to transfer from its general funds into the social security pension fund, and thus freed that money for other purposes (Reuters, 2014). In 2015, Russia announced that this policy would continue in 2016 (Social Security Administration, 2015a, b), and it subsequently has been extended at least through 2018 (Social Security Administration, 2018). 
Ukraine. In 2015, the Ukraine reduced social security pensions for some workers in an attempt to help finance the cost related to refugees who had been displaced by the Russian-led attack on the Ukraine (Ukraine Today 2015). Future social security benefits were reduced.

Cyprus. In Cyprus, a special tax of 3 percent is levied on interest income earned by defined contribution provident funds to provide extra financing for defense (OECD, 2015). Provident funds are government-managed defined contribution plans, where the government chooses the investments, rather than the individual account holders.

Disruption of contributions to social security during wars. Wars have disrupted the contributions to social security pensions in a number of countries, reducing the ability of governments to provide social security pensions.

Africa. During the wars in South Sudan (1983-2005) and Burundi (1993-2005), contributions were not collected by the social security programs. In Liberia, and in the neighboring Central African countries of the Republic of the Congo and the Democratic Republic of the Congo, social security programs have been totally or substantially destroyed by war (Gillion, Turner, Bailey, \& Latulippe, 2000).

Destruction of administrative records. The destruction of social security administrative records reduces the ability of government to provide social security pensions.

Kosovo. The war between Serbia and Kosovo (1998-99) resulted in the destruction of the social security pension system in Kosovo, which was targeted by Serbia, including the destruction of social security contribution records and personal identification records. For three years after the war, no social security benefits were paid, then a flat benefit (the same for everyone) was paid as an interim solution. International aid agencies, including the World Bank, helped Kosovo start a new social security pension system based on funded individual accounts (ILO, 2010).

\section{War causing a regime change}

War can affect the government provision of pension systems through the victors' exercise of political power over defeated countries.

Africa. In pre-colonial Africa, social protection for people in old age was principally the responsibility of the extended family. The wars of European conquest that colonialized parts of Africa affected the pension programs that were subsequently established. A voluntary pension, the West African Retirement Pensions Fund, was established in a number of Francophone West African countries, such as Senegal and Mali, but these countries generally did not establish mandatory social security programs until after independence. After independence, many Francophone African countries developed earnings-based social security pensions. By contrast, prior to independence, many British colonies established defined contribution provident funds, including Gambia, Ghana, Kenya, Nigeria, Seychelles, Swaziland, the United Republic of Tanzania, Uganda and Zambia (Gillion, Turner, Bailey, \& Latulippe, 2000).

A survey of the development of social security provision in Africa finds, "Internal and external conflict has had a serious effect on the development and operation of schemes in many countries, such as Ethiopia, Eritrea and Somalia (where there is no social security pension for private sector workers), and Liberia, the Republic of Congo and the Democratic Republic of the Congo, where schemes have been totally or substantially destroyed" (Gillion, Turner, Bailey, \& Latulippe, 2000).

Central and Eastern Europe. The end of World War II brought communism to Central and Eastern Europe, which resulted in changes in social security systems in countries that became part of the Soviet Union or the Soviet bloc. Social security was financed out of government general revenues. Fragmented systems covering different groups of workers were unified into one national system, but with special programs for culturally important groups, such as teachers and ballet dancers (Social Security Administration, 1959).

Effects of war on pensions through effects on demography. The deaths of young soldiers are an obvious effect of war on the population age structure, but wars affect both mortality rates and fertility rates. The age structure of populations, in particular the old-age dependency ratio, plays an important role in determining the cost or shadow price of providing benefits through pay-as-you-go pension systems, a supply-side effect of war on pensions (Turner, 1984). The old-age dependency ratio is the ratio of beneficiaries to covered workers. The higher is the old-age dependency ratio, the more costly is it to raise benefits for beneficiaries.

The baby boom following World War II in the United States and other countries involved in that war has affected pay-as-you-go social security systems. With a roughly twenty-year lag, it led to a decrease in the old-age dependency ratio, as the large birth cohort entered the work force and made it easier to finance those systems, resulting often in benefit increases. Starting around 2010, as the baby boom generation started retiring, it is leading to an increase in the old-age dependency ratio and financing problems for many social security systems. 
Twenty-first century warfare: Cyber attacks on pension systems. In modern warfare, including cold wars, pension systems have been subject to cyber attacks, which are attacks on computer systems and computerized recordkeeping in order to obtain information relating to personnel and social security records. Cyber attacks are a new development and the implications of these attacks for social security systems are not yet fully known.

Japan. In 2015, the National Pension System of Japan, its social security pension system, was hit by a cyber attack that stole personal data for 1.25 million people (Kokhreidze, 2015). This attack served notice that pension system records should be protected, like other critical aspects of national infrastructure.

United States. In 2015, China hacked the personnel records of current and former government employees maintained by the U.S. government. The hack was not detected for five months. China apparently obtained the personnel records, including pension records and Social Security numbers, of all current and many former federal government workers. It appears that the Social Security numbers were not encrypted and were thus easily obtained. While the government of China has denied that it was the hacker, U.S. government officials have indicated that they view the Chinese government as the perpetrator of the attack (Nakashima, 2015).

\section{Employer-Provided Pensions}

In some respects, the effects of war on employer-provided pensions have differed from the effects of war on social security pensions. This section switches focus from the discussion of the effects of war on social security pension systems and discusses effects of war on employer-provided pensions.

\subsection{Pensions and Wage Controls}

United States. During World War II, the United States established price and wage controls to control inflation. However, companies were permitted to offer pensions as a way to attract workers without increasing their current disposable income, which provided an incentive for employers to offer pension plans. The tax incentive for pensions helped create demand among workers for employer-provided pensions. Also, pensions cost employers little in terms of profits because of the high wartime excess profits tax and the ability of employers to deduct the pension contributions when calculating the tax (Ellis, Munnell, \& Eschtruth, 2014).

\subsection{Destruction of Funded Employer-Provided Pensions in Hyperinflations Following War}

Similarly to hyperinflation affecting funded social security pensions, it also adversely affected funded employerprovided pensions.

Germany. Following World War II, Germany developed the system of book reserve financing of employerprovided pension plans because of the destruction of the banking system and the capital market due to hyperinflation. Forms of investment financing external to the firms were unavailable. Book reserves were a valuable source of internal financing for companies in the post-war period. Book reserve pension systems, such as currently used in Germany, are pension systems where the employer does not need to set aside a separate fund to finance the pension, but can instead finance the pension by entering the future benefits payments as a liability on the company's accounting books.

In addition, the Allied forces imposed marginal tax rates of up to 90 percent on company profits. By disclosing a liability for future pension payments, taxation (as well as wages) could be reduced and the retained funds could be used for reconstruction (Gerke et al. 2006).

\section{Summary of Effects of War on Social Security and Employer-Provided Pensions}

War has played a major role in the development of some social security and employer-provided pension systems, but its effects vary across countries and across wars. The effects tend to be greater the greater the destruction caused by the war. The effects differ between winners and losers. The effects differ between funded and unfunded pension systems.

In Table 1 we summarize the most important effects of war on pensions. While complex policy processes, such as the development of social security pension systems, are generally unlikely to have singular determinants, the effects of war in some countries have been so massive that in some cases war can be identified as a major factor in the development of social security pension systems. The most common short-term effect of wars was to prevent contributions to the social security system, subsequently leading to a partial or total loss of social security pensions. Another effect has been destruction of or interference with administrative records, whether due to the breakdown of civil administration or, in recent years, the development of cyber attacks on administrative records as part of an ongoing cold war.

Hyperinflation affected social security pensions in at least four countries in Europe (Austria, France, Germany, and Italy). Hyperinflation in those countries resulted in a loss of confidence in funded pensions and a commitment 
in the postwar period to pay-as-you-go financing for social security pensions. Other negative influences of war, such as using pensions to finance wars in Argentina, Cyprus, Japan and Russia, have had significant effects on the financing of social security pensions.

During and after World War II, France, Italy and the United Kingdom developed plans in response to demands from resistance groups, trade unions, workers, employers and social reformers, among others, for social security pensions. These demands were based on the need to foster solidarity during wartime and to demonstrate that after the war people could count on a system which would prevent them falling into poverty in old age.

War had positive effects on the demand for employer-provided pensions in the United States as wage and price controls resulted in favorable tax treatment for employees' contributions to private pensions. The destruction of industry in Japan resulted in employers offering pensions to attract long tenure employees. The destruction of the banking system and capital market and punitive tax rates on profits resulted in book reserve financing of pensions in postwar Germany. In these three countries, a significant proportion of the labor force eventually had an entitlement to employer-provided pensions which helped to maintain living standards in old age.

\section{Conclusions}

Social security pensions and employer-provided pensions have been affected by war. While various authors have commented on aspects of the effects of war, this paper presents a survey of the effects of war on pensions. In many countries, military pensions were the precursors to social security pensions. To organize the analysis, we use a simple demand-supply model focusing on factors affecting the demand for different types of pensions by workers and factors affecting the ability of government and employers to provide or supply different types of pensions.

War has affected the development of both Bismarckian pensions (earnings related) and Beveridgian pensions (based on years of work or contributions). It has affected the choice between funded and unfunded pensions. Through war, one country can have a major effect on the pensions in another country. This effect is seen in particular in post-colonial Africa.

While the short-term effects of war have sometimes been negative, the long-term effects often have been positive in the sense that they resulted in the creation and expansion of pension systems. Among the short-term effects of war, this paper examines their use as a source of financing for war. Because pension funds can contain substantial amounts of money, and because they can play an important role in providing income security, they have become an aspect of modern warfare. The paper also examines their being targeted in war in an attempt to destabilize the social structure of countries. Social security pensions have been used to encourage feelings of national solidarity during and after wars. A recent development, with as yet unknown consequences, is the targeting of social security records as an aspect of cyber warfare.

\section{Acknowledgements}

We have received helpful comments from Tianhong Chen, Lily Liu, Paul Roels, Junichi Sakomoto, Arnauld d'Yvoire, and from participants at the meeting of the European Network for Research on Supplementary Pensions (ENRSP) in Leuven, Belgium, the regional meeting of the International Public Policy Association (IPPA) in Hong Kong, and the meeting of the International Actuarial Association (IAA) in St. John's, Canada.

\section{References}

Arza, C., \& Johnson, P. (2006). The Development of Public Pensions from 1889 to the 1990s. In G. L. Clark, A. H. Munnell, \& J. M. Orszag (Eds.), The Oxford Handbook of Pensions and Retirement Income (pp. 52-75). Oxford: Oxford University Press. https://doi.org/10.1093/oxfordhb/9780199272464.003.0004

Bauer, M., Blattman, C., Chytilová, J., Henrich, J., Miguel, E., \& Mitts, T. (2016). Can War Foster Cooperation? Journal of Economic Perspectives, 30(3), 249-74. https://doi.org/10.1257/jep.30.3.249

Canadian Museum of History. (2015). Our First Old Age Pension, 1915-1927. Retrieved from http://www.historymuseum.ca/cmc/exhibitions/hist/pensions/1915-1927_e.pdf

Capretta, J. C. (2007). Global Aging and the Sustainability of Public Pension Systems: An Assessment of Reform Efforts in Twelve Developed Countries. Center for Strategic \& International Studies, January. Retrieved from http://csis.org/files/media/csis/pubs/pension_profile.pdf

Collier, D., \& Messick, R. E. (1975). Prerequisites versus Diffusion: Testing Alternative Explanations of Social Security Adoption. American Political Science Review, 69(4), 1299-1315. https://doi.org/10.2307/1955290

Craig, L. A. (2003). Public Sector Pensions in the United States. In R. Whaples (Ed.), EH.net encyclopedia. Economic History Association. Retrieved from https://eh.net/encyclopedia/public-sector-pensions-in-the- 
united-states/

Deacon, B. (2007). Global Social Policy and Governance. London: SAGE Publications.

Frizell, S. (2014). This Woman is the Last Civil War Pensioner Alive. Time, May 10. Retrieved from http://time.com/95195/civil-war-pensioner/

Gerke, W., Ferdinand, M., Timo, R., \& Christian, S. (2006). Empirical Risk Analysis of Pension Insurance: The Case of Germany. Discussion Paper Series 2: Banking and Financial Studies No. 07/2006. Deutsche Bundesbank. Retrieved from https://www.bundesbank.de/Redaktion/EN/Downloads/Publications/Discussion_Paper_2/2006/2006_09_06 _dkp_07.pdf?_blob=publicationFile

Gildea, R. (2003). Barricades and Borders. Europe 1800-1914 (3rd ed.). Oxford: Oxford University Press.

Gillion, C., Turner, J., Bailey, C., \& Latulippe, D. (Eds.). (2000). Social Security Pensions: Development and Reform. Geneva, Switzerland: International Labour Office.

Graham, A., \& Seldon, A. (1990). Government and Economies in the Postwar World: Economic Policies and Comparative Performance 1945-1985. London: Routledge. https://doi.org/10.4324/9780203167816

Gross, J. (2005). Civil War Pensions. In D. S. Heidler \& J. T. Heidler (Eds.), Encyclopedia of the American Civil War: A Political, Social and Military History. Retrieved from http://civilwarhome.com/pensions.html

Hagen, J. (2013). A History of the Swedish Pension System. Uppsala Center for Fiscal Studies, University of Uppsala. Retrieved from https://uu.diva-portal.org/smash/get/diva2:621560/FULLTEXT01.pdf

Heffernan, R. (2002). The Possible as the Art of Politics: Understanding Consensus Politics. Political Studies, 50(4), 742-60. https://doi.org/10.1111/1467-9248.00005

International Labour Organization (ILO). (1944). Declaration of Philadelphia. ILO: Geneva. Retrieved from http:/www.ilo.org/wcmsp5/groups/public/---asia/---ro-bangkok/---iloislamabad/documents/policy/wcms_142941.pdf

International Labour Organization. (2010). Profile of the Social Security System in Kosovo. Retrieved from http://www.ilo.org/wcmsp5/groups/public/---europe/---ro-geneva/---srobudapest/documents/publication/wcms_168770.pdf

Jones, E., Palmer, I., \& Wessely, S. (2002). War Pensions (1900-1945): Changing Models of Psychological Understanding. British Journal of Psychiatry, 180, 374-79. https://doi.org/10.1192/bjp.180.4.374

Judt, T. (2005). Postwar. A History of Europe since 1945. London: Pimlico.

Kasza, G. J. (2006). One World of Welfare: Japan in Comparative Perspective. Ithaca, NY: Cornell University Press. $\quad$ Retrieved from https://books.google.com/books?id=4NgkrTBXuKEC\&pg=PA43\&lpg=PA43\&dq=wartime+investing + pens ion\&source $=$ bl\&ots $=\mathrm{vXH} 3 \mathrm{sM} 7 \mathrm{c} 2 \mathrm{M} \& \mathrm{sig}=\mathrm{rtkrO}$ bq04W4iDccKijI0RtVWGM\&hl $=\mathrm{en} \& \mathrm{sa}=\mathrm{X} \& \mathrm{ved}=0 \mathrm{CEcQ}$ 6AEwA2oVChMI4OuMwo-

YyAIVwbgeCh3uxg9J\#v=onepage\&q=wartime\%20investing\%20pension $\& \mathrm{f}=$ false

Kavanagh, D., \& Morris, P. (1994). Consensus Politics from Atlee to Major (2nd Ed.). Oxford: Oxford University Press.

Keynes, J. M. (1980). Activities 1940-1946: Shaping the Post-War World, Employment and Commodities. In D. Moggridge (Ed.), The Collected Writings of John Maynard Keynes (Vo. 27). Cambridge: Cambridge University Press.

Kokhreidze, N. (2015). Japan Becomes a Target to Massive Cyber Attack, Days After US Vows to Protect the Country. Securityzap, June 2. Retrieved from http://securityzap.com/japan-cyber-attack-on-pension-found/

Lynes, T. (1985). Paying for Pensions: the French Experience. STICERD Occasional Paper No. 9. London: Suntory-Toyota International Centre for Economics and Related Disciplines, London School of Economics and Political Science.

Minns, R. (2007). "Estafa": Dictatorship, Debt, Weapons and Pensions in Argentina-An Alternative Perspective on Pension 'reform' in Latin America. Pensions, 12, 199-205. Retrieved from http://download.springer.com/static/pdf/283/art\%253A10.1057\%252Fpalgrave.pm.5950060.pdf?originUrl= http $\% 3 \mathrm{~A} \% 2 \mathrm{~F} \% 2 \mathrm{Flink}$.springer.com $\% 2$ Farticle $\% 2 \mathrm{~F} 10.1057 \% 2 \mathrm{Fpalgrave.pm} .5950060 \&$ token $2=\exp =14866$ 72386 acl $=\% 2$ Fstatic $\% 2 F p d f \% 2 F 283 \% 2 F a r t \% 25253$ A10.1057\%25252Fpalgrave.pm.5950060.pdf\%3Forig 
inUrl\%3Dhttp\%253A\%252F\%252Flink.springer.com\%252Farticle\%252F10.1057\%252Fpalgrave.pm.5950 060* ${ }^{*}$ mac $=a 63 d a 304 d 7 c d 9 d c 4 b 5 a 22 c c 584 c 41756 f 1333 f 7 a 2 e 7 f 039838 \mathrm{e} 8 \mathrm{f} 02 \mathrm{fc} 8881 \mathrm{bf} 6$

Nakashima, E. (2015). Chinese Breach Data of 4 Million Federal Workers. Washington Post, June 4. Retrieved from http://www.washingtonpost.com/world/national-security/chinese-hackers-breach-federal-governmentspersonnel-office/2015/06/04/889c0e52-0af7-11e5-95fd-d580f1c5d44e_story.html?wpisrc=al_alert-national

Natali, D. (2008). Pensions in Europe, European Pensions. The Evolution of Pension Policy at National and Supranational Level. Brussels: P.I.E. Peter Lang.

National Institute of Population and Social Security Research. (2014). Pensions. Social Security in Japan. Retrieved from http://www.ipss.go.jp/s-info/e/ssj2014/pdf/03_SSJ2014.pdf

Orenstein, M. A. (2008). Privatizing Pensions. The Transnational Campaign for Social Security Reform. Princeton, NJ: Princeton University Press. https://doi.org/10.1515/9781400837663

Organisation for Economic Co-operation and Development (OECD). (2015). Stocktaking of the Tax Treatment of Funded Private Pension Plans in OECD and EU Countries. Retrieved from http://www.oecd.org/daf/fin/private-pensions/Stocktaking-Tax-Treatment-Pensions-OECD-EU.pdf

Perotti, E., \& Schwienbacher, A. (2009). The Political Origin of Pension Funding. Journal of Financial Intermediation, 18(3), 384-404. https://doi.org/10.1016/j.jfi.2008.11.001

Pierson, C. (2004). The Modern State. Abingdon, Oxon: Routledge.

Reuters. (2014). Russia to Use Pension Savings as Short-Term Budget Fix for Second Year. The Moscow Times, August 5. Retrieved from http://www.themoscowtimes.com/business/article/russia-eyes-pension-savings-asshort-term-budget-fix/504611.html

Ring, M. D. (1943). Social Security for Great Britain: A Review of the Beveridge Report. Social Security Bulletin, 3-30. Retrieved from http://www.ssa.gov/policy/docs/ssb/v6n1/v6n1p3.pdf

Skocpol, T. (1992). Protecting Soldiers and Mothers. The Political Origins of Social Policy in the United States. Cambridge, Massachusetts: Harvard University Press.

Social Security Administration. (1959). Social Security in the Union of Soviet Socialist Republics. Social Security Bulletin, August, 3-7. Retrieved from http://www.ssa.gov/policy/docs/ssb/v22n8/v22n8p3.pdf

Turner, J. A. (1984). Population Age Structure and the Size of Social Security. Southern Economic Journal, 50(4), 1131-1146. https://doi.org/10.2307/1058439

U.S. Social Security Administration. (2014). A Hope of Many Years: A Brief History of Social Insurance. Retrieved from http://www.ssa.gov/history/video/

U.S. Social Security Administration. (2015a). Russia: New Public Pension Law Implemented. International Update. Retrieved from https://www.ssa.gov/policy/docs/progdesc/intl_update/2015-02/index.html\#russia

U.S. Social Security Administration. (2015b). Russia: Second-pillar Contributions Continue to be Diverted to the First Pillar in 2016. International Update, October. Retrieved from https://www.ssa.gov/policy/docs/progdesc/intl_update/2015-10/index.html\#russia

U.S. Social Security Administration. (2018). Russia. Social Security Programs Throughout the World: Europe, 2018. Retrieved from https://www.ssa.gov/policy/docs/progdesc/ssptw/2018-2019/europe/russia.html

Ukraine Today. (2015). Ukrainian Parliament Approves Batch of Reforms Needed for IMF Loan. Retrieved from http://uatoday.tv/politics/ukrainian-parliament-approves-reforms-needed-for-imf-loan-413004.html

Watanabe, N. (1996). Private Pension Plans in Japan. In Z. Bodie, O. S. Mitchell, \& J. A. Turner (Eds.), Securing Employer-Based Pensions: An International Perspective (pp. 121-42). Philadelphia: University of Pennsylvania Press.

Wikipedia. (2017). Chelsea Pensioner. Retrieved from https://en.wikipedia.org/wiki/Chelsea_pensioner 
Table 1. Major effects of war on pensions

\begin{tabular}{|c|c|c|c|c|c|c|}
\hline & $\begin{array}{l}\text { Military } \\
\text { pensions as } \\
\text { precursor to } \\
\text { social security }\end{array}$ & $\begin{array}{l}\text { Expansion of } \\
\text { social security } \\
\text { fosters solidarity }\end{array}$ & $\begin{array}{l}\text { Hyperinflation } \\
\text { destroys funded } \\
\text { schemes }\end{array}$ & $\begin{array}{l}\text { Use } \\
\text { contributions to } \\
\text { pay for war }\end{array}$ & $\begin{array}{l}\text { Disruption, } \\
\text { destruction, or } \\
\text { cyber attack on } \\
\text { contributions or } \\
\text { administrative } \\
\text { records } \\
\end{array}$ & $\begin{array}{l}\text { Regime change or } \\
\text { victor imposes a } \\
\text { pension system }\end{array}$ \\
\hline Country & $\begin{array}{lr}\text { Canada } & \text { Ireland } \\
\text { Sweden } & \text { U.K. } \\
\text { U.S.A. } & \end{array}$ & $\begin{array}{l}\text { Germany Japan } \\
\text { U.K. }\end{array}$ & $\begin{array}{l}\text { Austria France } \\
\text { Germany Italy }\end{array}$ & $\begin{array}{l}\text { Argentina } \\
\text { Cyprus Japan } \\
\text { Russia }\end{array}$ & $\begin{array}{l}\text { Burundi Dem. } \\
\text { Rep of Congo } \\
\text { Liberia Rep. of } \\
\text { Congo } \\
\text { South Sudan } \\
\text { Japan } \\
\text { U.S.A }\end{array}$ & $\begin{array}{lr}\text { Ethiopia } & \text { Eritrea } \\
\text { Gambia } & \text { Ghana } \\
\text { Hungary } & \text { Iraq } \\
\text { Kenya Mali Nigeria } \\
\text { Poland } & \text { Senegal } \\
\text { Seychelles } & \text { Somalia } \\
\text { Swaziland Tanzania } & \text { Tganda Zambia }\end{array}$ \\
\hline
\end{tabular}

Sources: see text.

\section{Copyrights}

Copyright for this article is retained by the author(s), with first publication rights granted to the journal.

This is an open-access article distributed under the terms and conditions of the Creative Commons Attribution license (http://creativecommons.org/licenses/by/4.0/). 